\title{
Field availability and mobility of metals in Ferralsols developed on ultramafic rock of Niquelândia, Brazil
}

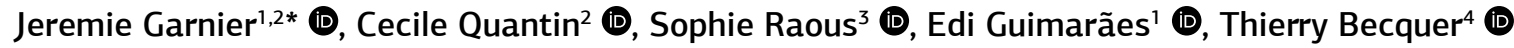

\begin{abstract}
Ultramafic (UM) rocks are defined as igneous rocks that contain more than $90 \%$ of mafic minerals. Soils derived from ultramafic rock are generally nutrient-deficient and have concomitant high concentrations of potentially phytotoxic trace elements $(\mathrm{Ni}, \mathrm{Cr}, \mathrm{Co}, \mathrm{Mn})$. Consequently, to assess the dynamics of nutrients and metals in the ultramafic complex of Niquelândia (Brazil), soil solutions have been sampled in soils characterized by high $\mathrm{Cr}(\mathrm{VI})$ availability. The metal contents in surficial water have also been analyzed to investigate the metals' leaching and mobility. Soil solutions featured low nutrient contents, a large $\mathrm{Ca}: \mathrm{Mg}$ imbalance, and high $\mathrm{Ni}$ and $\mathrm{Cr}$ concentrations. Chromium was present in its toxic dissolved form $(\mathrm{Cr}(\mathrm{VI}))$ in the soil and surficial solutions. Metals concentrations were often above the toxic limit for biota and were therefore able to affect soil functioning. Ni behavior in the topsoil appeared to be primarily controlled by organic matter, while $\mathrm{Cr}$ was more likely to be released from Fe-oxides by anionic exchange. This result agreed with the $\mathrm{Cr}(\mathrm{VI})$ lability assessed using isotopic exchange kinetics in a companion study. In these serpentinic tropical soils, the highly leached Fe-oxide horizons appear to play a large role in the sequestration and diffuse leaching of labile $\mathrm{Cr}(\mathrm{VI})$ and $\mathrm{Ni}$, respectively, in the deeper part of soil profiles and the topsoil. At the catchment scale, surficial solutions results suggest that metals may be exported to surrounding ecosystems that are not adapted to these metals.
\end{abstract}

KEYWORDS: chromium; nickel; soil solution; runoff; serpentine syndrome; metal toxicity.

\section{INTRODUCTION}

Ecosystems developed on ultramafic (UM) rocks have long been known as unique (1). Serpentinitic or ultramafic substrates are harsh environments for biota due to their low levels of nutrients (N, P, and $\mathrm{K})$, the imbalance between calcium $(\mathrm{Ca})$ and magnesium $(\mathrm{Mg})$, and the presence of metals, such as nickel $(\mathrm{Ni})$, chromium $(\mathrm{Cr})$ and cobalt $(\mathrm{Co})$ (Whittaker 1954, Brooks 1987, Kazakou et al. 2008, Pędziwiatr et al. 2018). These chemical characteristics have contributed greatly to the consideration of certain ultramafic ecosystems as "hot spots" of biodiversity (Myers et al. 2000). Moreover, the chemical characteristics of UM ecosystems explain the major ecological traits of these environments, which are often called the serpentine syndrome:

\section{Supplementary data}

Supplementary data associated with this article can be found in the online version: Supplementary Table and Figure.

${ }^{1}$ Instituto de Geociências, Instituto Central de Ciências, Campus Universitário Darcy Ribeiro, Universidade de Brasília - Brasília (DF), Brazil.E-mails: garnier@unb.br, rxedi@unb.br

${ }^{2}$ French National Centre for Scientific Research, Université Paris Saclay Orsay, Cedex, France. E-mail: cecile.quantin@u-psud.fr

${ }^{3}$ Institut Régional du Développement Durable - Abbaye aux Dames, Cedex, France. E-mail: sophieraous@gmail.com

${ }^{4}$ UMR Eco\&Sols, Institut de Recherche pour le Développement Montpellier, Cedex, France. E-mail: thierry.becquer@ird.fr

${ }^{*}$ Corresponding author.
- low plant productivity;

- a high degree of endemism;

- vegetation types distinct from those of neighboring areas;

- the presence of certain "hyperaccumulators" of metals (Ni) (Jaffré et al. 1976, Proctor and Nagy 1992, Reeves et al. 2007, Kazakou et al. 2008, Anacker 2014, Bini et al. 2017, Kanellopoulos et al. 2015, Ratié et al. 2018, 2019).

These features are magnified in tropical areas where strong leaching conditions have led to the formation of deep lateritic profiles.

Tropical soils developed in ultramafic rock have been widely studied due to their edaphic particularities and lateritic Ni mining. However, most of the research has focused on the solid component, including subjects such as soil characteristics, mineral compositions, metal solid speciation behavior, and more recently, Ni isotopic compositions (Quantin et al. 2002, Oze et al. 2004, Becquer et al. 2006, Fandeur et al. 2009, Dublet et al.2012, Ratié et al.2015, Hseu et al.2017). During the past few decades, the availability of $\mathrm{Ni}$ and hexavalent $\mathrm{Cr}$ has been highlighted by laboratory investigations of tropical soils developed in ultramafic rock from New Caledonia (Quantin et al. 2002, Becquer et al. 2003, Becquer et al. 2006). Metal concentrations in "ultramafic" soil solutions remain incompletely and poorly documented (Anderson et al. 1973, Johnston and Proctor 1981, Gasser et al. 1994), particularly under tropical conditions. However, a recent investigation of soil solutions from New Caledonia has shown significant concentrations of metals in toxic forms, i.e. free-ion species (Becquer et al. 2010). The concentration, speciation and availability of $\mathrm{Cr}$ 
have been studied in soils of the Niquelândia ultramafic massif in Brazil. The high availability of $\mathrm{Cr}$ in its most toxic form, i.e., hexavalent $\mathrm{Cr}(\mathrm{Cr}(\mathrm{VI}))$, has been quantified using several laboratory approaches, that is, chemical extractions, kinetics and XANES isotopic exchange (Garnier et al. 2006, Garnier et al. 2009a, Garnier et al. 2013).

Metals, such as $\mathrm{Co}, \mathrm{Cr}, \mathrm{Mn}$, and $\mathrm{Ni}$, are known to be potentially toxic in soils, even at low concentrations, and may lead to major limitations to root and leaf development and even the death of non-adapted organisms. The phytotoxicity of such metals depends on their mobility, uptake, and biological impact (Anderson et al. 1973, Sharma et al. 1995, L'Huillier and Edighoffer 1996, Samantary 2002, Becquer et al. 2010). Therefore, in addition to their concentrations, the phytotoxicity of metals in soil solutions is controlled by speciation, complexation with organic and/or inorganic components, ionic strength, $\mathrm{pH}$, and exposure duration. Moreover, the uptake of metals by roots and microorganisms is complex and depends on bio-physico-chemical interactions in the solid-solution-biota continuum (Alexander 2000, Zayed and Terry 2003).

A large spatiotemporal variability in soil solution composition is expected with regard to different edaphic conditions. Thus, soil solution sampling under field conditions, with native biota and seasonal climate variations, is complementary to laboratory approaches that study potential metal availability, fate, and toxicity. Field approaches and large datasets that describe the spatial and temporal variations in soil solution composition are essential and required to identify the main processes that control the release and mobility of both nutrients and metals concentrations.

Due to the relatively high metals concentrations of UM bedrock ( $\mathrm{Ni}, \mathrm{Co}$, and $\mathrm{Cr}$ ), weathering products can represent an important source of metals for surface and groundwater. Nonetheless, in UM complexes, few authors have previously reported natural transfers of trace elements (Weng et al. 1994, Robles-Camacho and Armienta 2000, McClain and Maher 2016). In the Putah Creek watershed (California Coast Range Mountains, USA), riverine Cr concentrations and speciation in ultramafic catchments are governed by the balance between ultramafic rock weathering and elemental cycling along water flow paths, mainly by the availability of electron donors and acceptors (e.g. Fe(II), organics, $\mathrm{Mn}(\mathrm{III} / \mathrm{IV}$ )-oxides) (Mcclain and Maher 2016). In addition, the exported dissolved $\mathrm{Cr}$ can occur as soluble hexavalent $\mathrm{Cr}(\mathrm{VI})$ species $\left(\mathrm{CrO}_{4}^{2-}, \mathrm{MgCrO}_{4}\right)$, and as trivalent $\mathrm{Cr}$ species $\left(\mathrm{Cr}(\mathrm{OH})_{3}, \mathrm{CrOH}\left(\mathrm{CO}_{3}\right)_{2}{ }^{2-}\right)$ (Mcclain and Maher 2016). Concentrations of $\mathrm{Cr}$ as high as $19 \mu \mathrm{g} . \mathrm{L}^{-1}$ have been reported in surface waters (Kruckeberg 1984, McClain and Maher 2016). However, the sources, fate, and fluxes of natural $\mathrm{Cr}(\mathrm{VI})$ remain poorly inventoried. Speciation is a key parameter controlling both the mobility of metals, e.g., their potential transfer from a soil profile to water resources, and the eco-toxicological consequences (Kalis et al. 2008, Brown Jr. and Calas 2011). Dispersion of geogenic contaminants (in this paper, metals) is a crucial environmental issue in ecosystems developed in lateritic terrains, whose source rocks were ultramafic mineralized in nickel, sometimes chromium (e.g., New Caledonia, Brazil, the Philippines, and Indonesia), particularly under anthropogenic pressures, such as mining and mineral extraction.

A long-term investigation of the serpentine syndrome, metal availability and metal mobility associated with the soils and surface solutions of Niquelândia (Goiás State, Brazil) is required to complete our knowledge of metal behavior in natural soils developed in UM rocks, i.e., to understand whether and, if so, how metal mobility occurs. The aims of this study based on field approach were, therefore, to assess to the metal availability in two soils developed in ultramafic rock known to present large nickel and chromium contents. In addition, to address the possible mobility of metals and transfer to surrounding areas, metal contents in surface waters were monitored during a complete hydrological cycle.

\section{MATERIALS AND METHODS}

\section{Site and materials}

The study area is located in the ultramafic complex of Niquelândia, Goiás, Brazil (S14¹8'-E48 $\left.23^{\prime}\right)$. The regional climate is tropical humid; the region experiences an annual average temperature of $20^{\circ} \mathrm{C}$ and receives rainfall amounting to $1,500 \mathrm{~mm}$. Two contrasting seasons are present: a wet and hot season occurs from November to April, and a dry season occurs from May to October. The vegetation, which is dominated by herbaceous plants and bushes, is similar to "Campo limpo" (Cerrado), a portion of the Brazilian Savanna dominated by grasses and herbaceous subshrubs. Several Ni-hyperaccumulating plants have been found in the ultramafic complex and have been described by Reeves et al. (2007), such as Justicia Lanstyakii., Heliotropium aff. salicoide., and Cnidoscolus aff. urens.

Two Geric Ferralsols (NIQII and NIQIII; WRB, 2006) located on the footslope of a toposequence representative of the Niquelândia massif and previously described by Garnier et al. $(2006,2009 \mathrm{~b})$ were selected for this study due to their high Cr(VI) lability (Garnier et al. 2006, 2009b, 2013).

The studied soils (NIQII and III) come from the massif consists of a hilly landscape controlled by a level of silcrust (a hardened accumulation of silica) and containing eroded backslope and footslope composed of debris stripped from the entire landscape (Fig. 1). The weathering profiles are characterized by the presence of a relatively thick upper Fe-rich zone overlying a saprolite containing Mg-Ni clay silicates ("garnierite") in contact with the ultramafic bedrock (Garnier et al. 2009b). The mineralogy of the soils is dominated by iron oxides (goethite and haematite); other accessory minerals are also present, such as chromite and quartz (Garnier et al. 2009b). These soils are particularly rich in $\mathrm{Fe}$, with more than $400 \mathrm{~g}$ $\mathrm{kg}^{-1}$, and feature high concentrations of "trace" metals, such as $\mathrm{Ni}$ and $\mathrm{Cr}$ (3,156-6,252 and 5,687-9,268 $\mathrm{mg} \mathrm{kg}^{-1}$, respectively) (Suppl. Tab.). The organic $\mathrm{C}$ content ranges between 20 and $22 \mathrm{~g} \mathrm{~kg}^{-1}$ in the surface horizons and decreases rapidly with depth (Suppl. Tab.). 


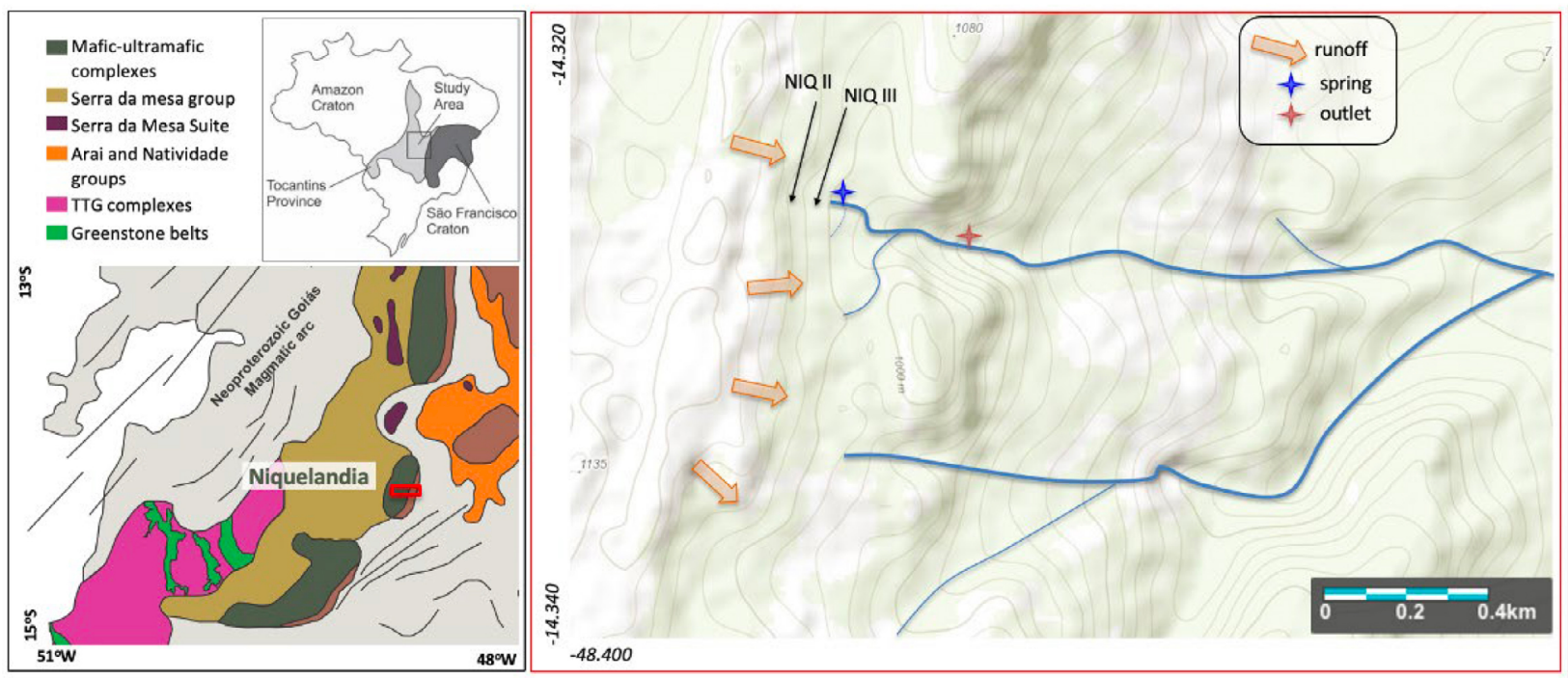

Figure 1. The map and sampling sites of the Niquelândia toposequence (S14.3034 - W48.3973; adapted from Cordeiro and Oliveira (2017) and Garnier et al. (2009b), location of waters sampling.

\section{Water sampling}

Soil solutions were collected from plots under natural vegetation developed on the Ferralsols NIQ II and NIQ III (Fig. 1). Ceramic cup samplers (No. 653X02B1 M3, Soilmoisture Equipment Corp., Goleta, CA, USA) were used. Studies that have tested the metal sorption in these ceramic cups have shown that they are suitable for monitoring metal concentrations in soil solutions, with the exception of $\mathrm{Cr}$ (III) (Becquer et al. 2003, Becquer et al. 2010). After cleaning with $1.10^{-3} \mathrm{M} \mathrm{HCl}$ and rinsing the ceramics with ultrapure water four times, the samplers were carefully inserted into the soil at depths of 20,70, and $150 \mathrm{~cm}$ for NIQII and 20 and $150 \mathrm{~cm}$ for NIQ III. For each ceramic cup, a soil hole has been previously opened using a soil sampler. Six replicates were collected at each depth. The soil solutions were sampled approximately every 2 weeks between December 2006 and June 2007 (i.e., during the rainy season until water was no longer extractable) and again in February 2008. It was possible to collect soil solutions at $20 \mathrm{~cm}$ depth until April 2007, and deeper samples could be collected until June 2007. Typically, 50 to more than $500 \mathrm{ml}$ of solution was collected at each sampling location and depth, depending on the seasonal period, but sometimes no water could be extracted because the soil was dry. After $\mathrm{pH}$ measurement, the soil solutions were filtered using cellulose membranes $(0.22 \mu \mathrm{m})$ and separated into three aliquots in the field. The first aliquot was acidified with pure $\mathrm{HNO}_{3}$ for cation analysis and stored at $4^{\circ} \mathrm{C}$. Cations were measured using ICP-AES (Varian Liberty 200 at UPS-GEOPS Laboratory). As $\mathrm{Cr}$ (III) is known to sorb onto the ceramic cups, the $\mathrm{Cr}$ measured in the soil solutions was expected to be hexavalent (Becquer et al. 2010). Nevertheless, a few hours after sampling, the $\mathrm{Cr}$ valence was verified in the second aliquot using the 1,5-diphenylcarbazide (DPC) method described by Bartlett and James (1996). Inorganic anions were analyzed in the second aliquot using an ionic chromatograph (Dionex ICS1000 at UPS Laboratory) equipped with an IonPac AS14
(Dionex) column and conductivity detection. The eluent was $3.5 \mathrm{mM} \mathrm{Na}_{2} \mathrm{CO}_{3}$ and $1.0 \mathrm{mM} \mathrm{NaHCO}_{3}$ under isocratic conditions with a flow rate of $1.2 \mathrm{ml} \mathrm{min}^{-1}$. The third aliquot was also stored at $4^{\circ} \mathrm{C}$ until analyses of anions and dissolved organic carbon (DOC) were performed. DOC concentrations were determined using a TOC-Vcsh Shimadzu analyzer, calibrated using potassium hydrogen phthalate (Fisher Scientific, Analytical Reagent grade) with an accuracy of $0.01 \mathrm{mmol} \mathrm{C} \mathrm{L}^{-1}$. Uncertainties were lower than 5\%, and the detection limits calculated for ICP-AES, DPC, and ionic chromatography were $0.001,0.002$, and $0.002 \mathrm{mmol} \mathrm{L}^{-1}$, respectively. A water internal standard was used to check the validity and reproducibility of each water analysis (less than $5 \%$ using the same instrument). As it was not possible to measure it in the field, the alkalinity of the samples was calculated as the difference between the cation and anion concentrations.

Rainwater (collected twice on 01/29/2007 and $03 / 14 / 2007$ ) and water from the nearby stream draining the studied catchment area were both analyzed. The stream water was regularly collected at the spring and at its outlet at the ultramafic complex boundary 8 and 7 times in 2007, respectively (Fig. 1). These samples were analyzed using the same procedures as those applied to the soil solutions. Rain infiltration is highly efficient and rapid in both of the studied Ferralsols, as observed by Reatto et al. (2007). Nevertheless, runoff has occasionally been observed in the field during rainstorms. Thus, runoff solution samples $(n=3)$ were taken from temporary streams on the footslope uphill of NIQ II during three heavy rain events. The same methodologies have been used to analyze the concentrations of cations, $\mathrm{Cr}(\mathrm{VI})$, anions, and DOC of surface samples.

In both soil solutions and surface waters, chromium has been found entirely in the hexavalent form due to the total concentrations $\left(\mathrm{Cr}_{\text {tot }}=\mathrm{Cr}(\mathrm{III})+\mathrm{Cr}(\mathrm{VI})\right)$ determined via ICP-AES and $\mathrm{Cr}(\mathrm{VI})$ determined via DPC having been statistically equivalent $(\mathrm{p}>0.70)$. 
Simplified Pourbaix diagrams were generated from the average water compositions and physicochemical parameters of the surface waters collected during the experiment. This was performed using the Act 2 module of the Geochemist Workbench (GWB) 14 software.

Since colloidal particles have been proven to play a key role in metal mobility in solutions of soils developed on ultramafic rock (Gasser et al. 1994, Zelano et al. 2013, Bolaños-Benítez et al.2018), a special investigation was conducted using all solutions sampled during the sampling of February 2008, including runoff waters. A size fractionation approach was performed on soil and surface solutions using the frontal cascade filtration technique (Patel-Sorrentino et al. 2007, Garnier et al. 2011). In the field, solutions were successively filtered at nominal cut-offs of $0.22 \mu \mathrm{m}, 0.025 \mu \mathrm{m}$, and $10 \mathrm{kDa}$, leading to the collection of four $\theta$ fractions (unfiltered, $\theta_{0} ; 0.22>\theta_{1}>0.025 \mu \mathrm{m} ; 0.025>\theta_{2}$ $\left.>10 \mathrm{kDa} ; 10 \mathrm{kDa}>\theta_{3}\right)$. The first filtration was performed using a syringe filter holder, and the $0.025 \mu \mathrm{m}$ and $10 \mathrm{kDa}$ filtrations were performed under $\mathrm{N}_{2}$ pressure with acetate membranes and polyethersulfone Millipore membranes, respectively, in a $47 \mathrm{~mm}$ filter holder.

\section{RESULTS}

\section{Soil solution}

The $\mathrm{pH}$ of the soil solutions was slightly acidic, ranging from $5.60 \pm 0.15$ to $6.10 \pm 0.08$, and increased slightly with depth in both soils (Tab. 1). At a depth of $20 \mathrm{~cm}$, the $\mathrm{pH}$ was low ( $\mathrm{pH}$ 5.60-5.70) at the beginning of the rainy season (Dec. 2006 - Jan. 2007) and subsequently increased. At deeper levels, the $\mathrm{pH}$ fluctuations were smaller, and the $\mathrm{pH}$ remained close to $\mathrm{pH} 6.00$ during the entire sampling period (Fig. 2).

Cations concentrations in soils solutions were always low, ranging from 4.7 to $58.0 \mu \mathrm{mol} \mathrm{L}^{-1}$ (Tab. 1), with Silicon $(\mathrm{Si})$ as the most abundant element, followed by cations $\mathrm{Mg}$, $\mathrm{Ca}$, and $\mathrm{Na}$

Table 1. $\mathrm{pH}$ and $\mathrm{Mg}, \mathrm{Ca}, \mathrm{Na}, \mathrm{Si}, \mathrm{Cr}, \mathrm{Ni}$, and $\mathrm{Mn}$ mean concentration of the soils solutions from NIQ II and NIQ III and the surfaces water. (All the water were filtered at $0.2 \mu \mathrm{m}$; d.l. detection limit; $\mathrm{X} \pm \mathrm{Y}$ mean $\pm \mathrm{SD}$., min / max value minimum and maximum observed). The $\mathrm{K}, \mathrm{Al}$, and Fe content of all solutions filtered were always below detection limit (< d.l.).

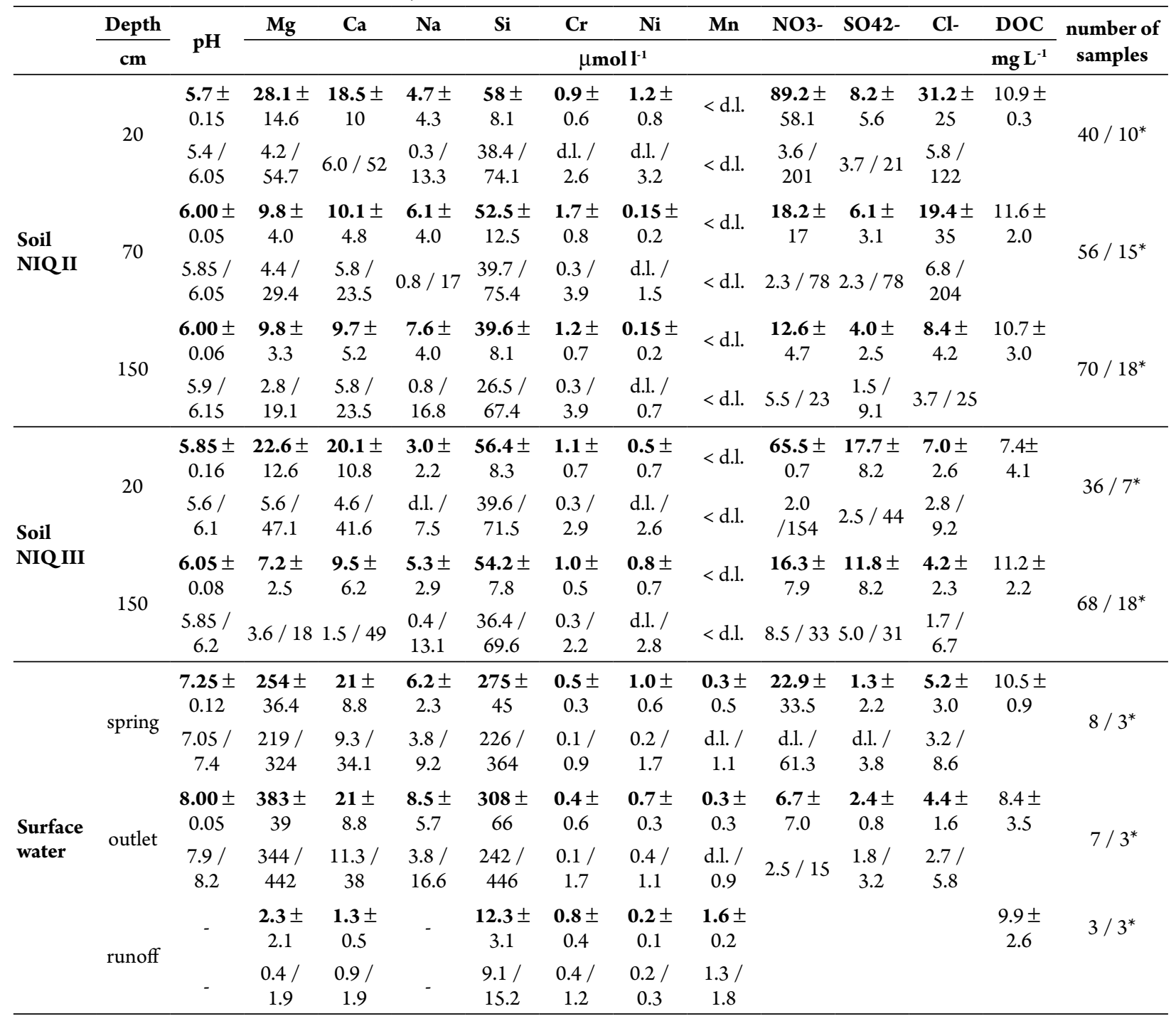

${ }^{*}$ Number of analyses of dissolved organic carbon. 


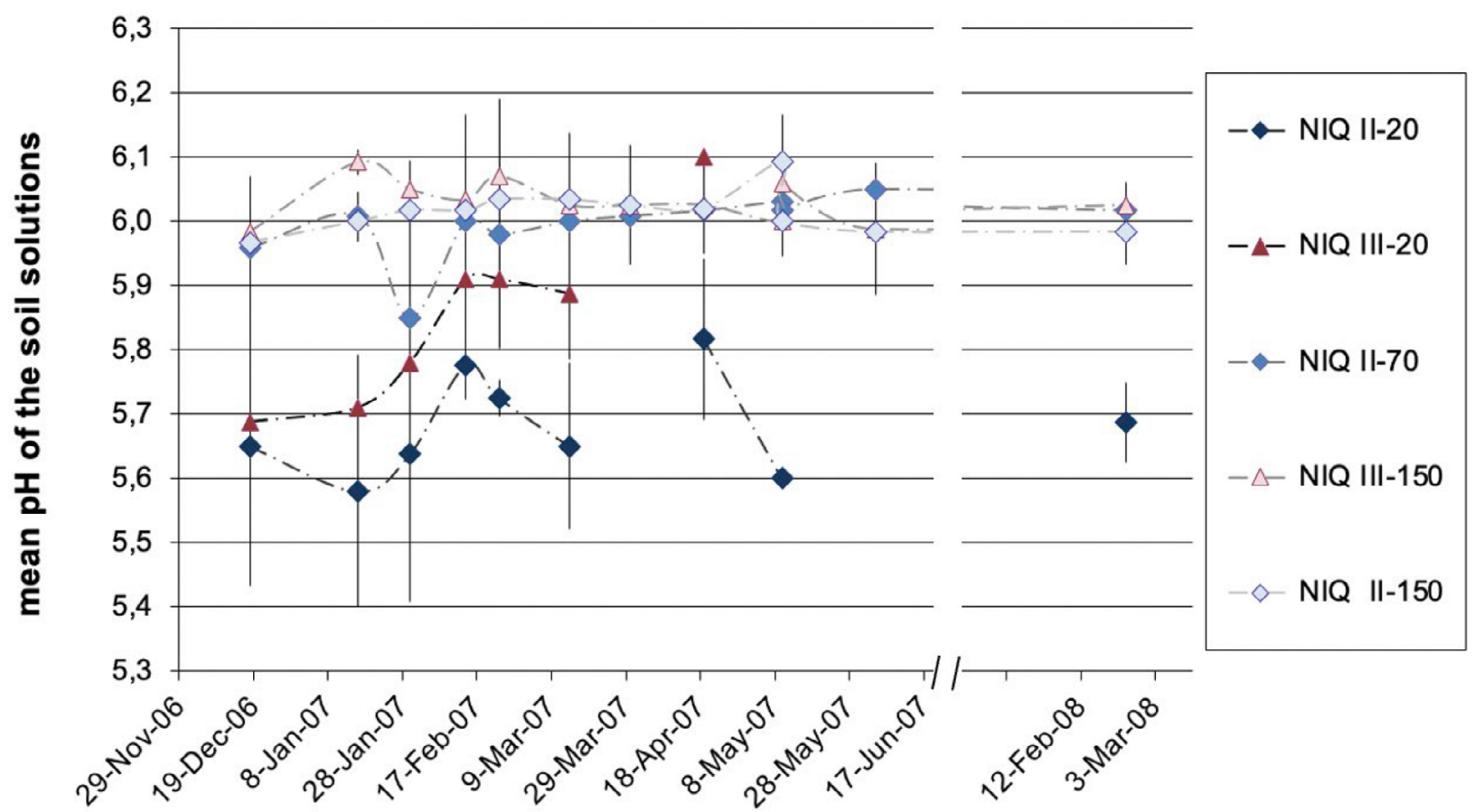

Figure 2. Mean pH of the soil's solutions from NIQ II-20, 70 and 150 and from NIQ III-20 and 150 (20, 70, and 15 refer of the sampling depth in $\mathrm{cm}$ ).
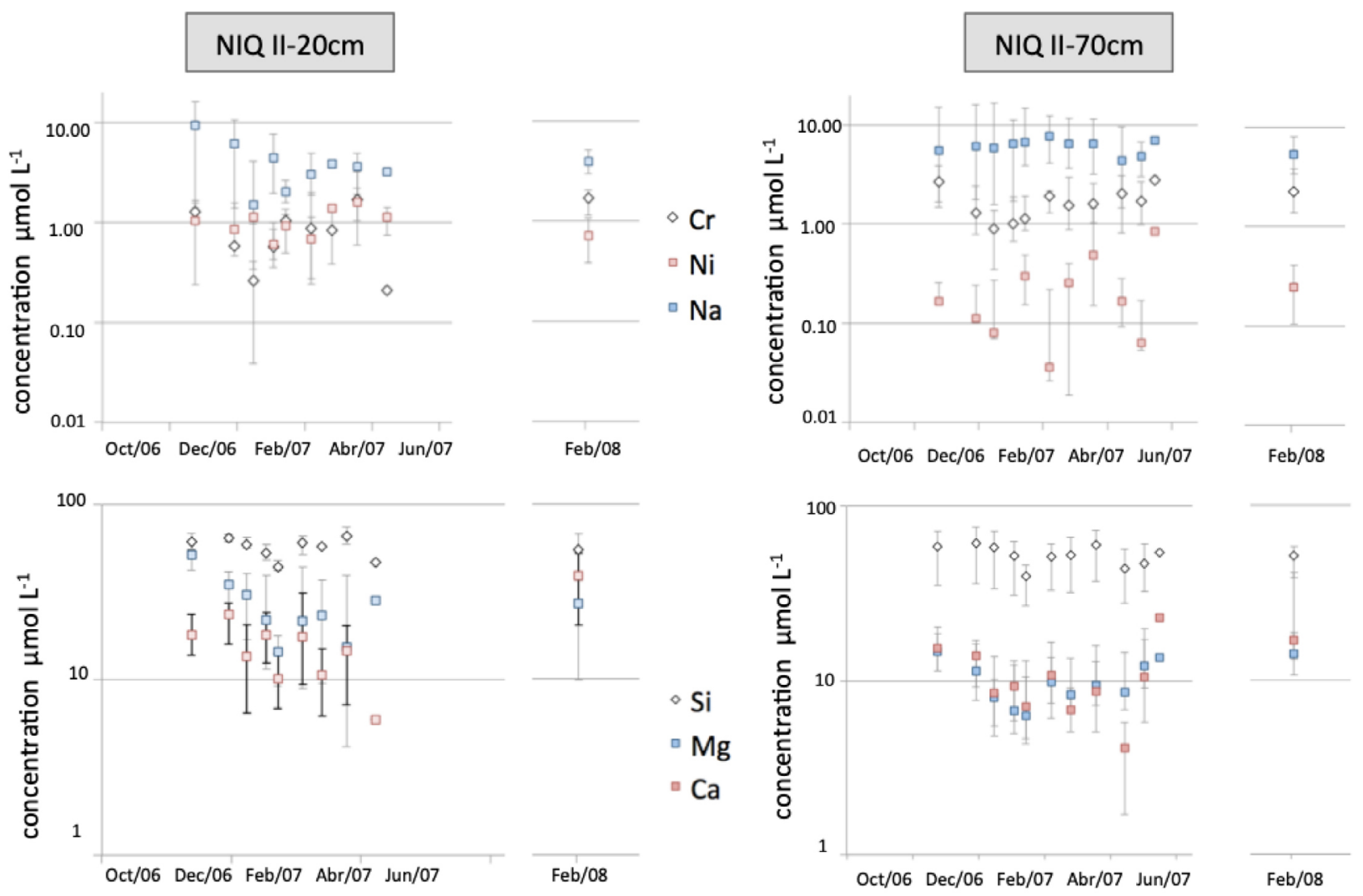

Figure 3. $\mathrm{Si}, \mathrm{Ca}$, and $\mathrm{Cr}$ concentrations for all NIQ II-20, 70, and 150 ceramics cups ( $\mathrm{Si} \mathrm{a}, \mathrm{b}$ and c; Ca d, e and f; Cr g, h and i), in $\mu \mathrm{mol}$ $\mathrm{L}^{-1}$ from December 2006 to June 2007; (•soils solution of February 2008) (20, 70, and 15 refer of the sampling depth in $\mathrm{cm}$ ).

(Tab. 1 and Fig. 3). In NIQII, Si concentrations decreased with depth, whereas they were homogeneous in the NIQ III solutions (Tab.2). Calcium concentrations decreased with depth from 18.5 \pm 10.0 to $9.7 \pm 5.2 \mu \mathrm{mol} \mathrm{L}^{-1}$ in NIQ II and from $20.1 \pm 10.8$ to 9.5 $\pm 6.2 \mu \mathrm{mol} \mathrm{L}^{-1}$ in NIQIII (Tab. 1 ). $\mathrm{Mg}$ concentrations at $20 \mathrm{~cm}$ were slightly higher than those of $\mathrm{Ca}$ for both soils and ranged from $28.1 \pm 14.6$ to $22.6 \pm 12.6 \mu \mathrm{mol} \mathrm{L}^{-1}$ in both NIQ II and NIQ III; the values in both soils decreased considerably with depth (Tab. 1). The Ca: $\mathrm{Mg}$ ratios ranged from 0.65 to 0.88 at a $20 \mathrm{~cm}$ depth and increased to 1 and 1.32 in the deeper parts of the profiles. 
Braz. J. Geol. (2021), 51(1): e20200092

Table 2. Mean Ca:Mg ratios of leaching topsoil solutions (C.P. Ceramic Cup).

\begin{tabular}{|c|c|c|c|c|c|c|c|c|c|c|}
\hline & \multicolumn{6}{|c|}{ Mean 2006-2008 } & & & & \\
\hline & C.P.1 & C.P. 2 & C.P. 3 & C.P.4 & C.P. 5 & C.P.6 & & & & \\
\hline $\begin{array}{l}\text { NIQII-20 } \\
\text { samplers }\end{array}$ & 1.6 & 1.4 & 1 & 1.6 & 0.7 & 0.9 & & & & \\
\hline \multirow[t]{3}{*}{$\begin{array}{l}\text { NIQ III-20 } \\
\text { samplers }\end{array}$} & 2 & 1.4 & 1.1 & 2.8 & 1.5 & - & & & & \\
\hline & \multicolumn{10}{|c|}{ Date of sampling } \\
\hline & $12 / 19 / 06$ & 01/17/07 & 01/31/07 & $02 / 15 / 07$ & $02 / 24 / 07$ & 03/15/07 & 03/30/07 & 04/18/07 & 05/10/07 & $02 / 25 / 08$ \\
\hline $\begin{array}{l}\text { NIQII-20 } \\
\text { mean }\end{array}$ & 0.6 & 1.1 & 0.9 & 1 & 1 & 1.5 & 0.9 & 2.3 & 0.3 & 2.7 \\
\hline $\begin{array}{l}\text { NIQ III-20 } \\
\text { mean }\end{array}$ & 1.2 & 1.5 & 1.3 & 2.1 & 1.5 & 2.6 & - & 2.5 & - & - \\
\hline
\end{tabular}

The variability of the Ca: $\mathrm{Mg}$ ratio at $20 \mathrm{~cm}$ depth was particularly high (Tab. 2). Finally, the concentrations of Na were very low and variable, ranging between 3 and $7.6 \mu \mathrm{mol} \mathrm{L}^{-1}$, and the concentrations of $\mathrm{K}$ were below the quantification limit (Tab. 1).

The dominant inorganic anions were $\mathrm{NO}_{3}{ }_{3}^{-}$and, to a lesser extent, $\mathrm{SO}_{4}^{2-}$ and $\mathrm{Cl}^{-}$(Tab. 2). In soil solutions, the concentration of anions, particularly $\mathrm{NO}_{3}$; decreased below $20 \mathrm{~cm}$. The concentrations of other anions, such as $\mathrm{H}_{2} \mathrm{PO}_{4}$; were always below the detection limit. The DOC concentration in the soil solution was homogeneous in both soil profiles and ranged between $7.4 \pm 4.1$ and $11.6 \pm 2.0 \mathrm{mg} \mathrm{L}^{-1}$.

Metal concentrations in the soil solutions were more variable among the soil profiles and during the seasonal cycle. Iron, $\mathrm{Al}$, and $\mathrm{Mn}$ concentrations were below the detection limits throughout the sampling period (Tab. 1). Mean Ni concentrations varied from $0.15 \pm 0.2$ to $1.2 \pm 0.8 \mu \mathrm{mol} \mathrm{L}^{-1}$ (Tab. 1 ) and decreased drastically with depth for NIQII, but increased slightly with depth in NIQ III. Ni concentrations were heterogeneous both spatially and temporally, particularly in NIQ III. For example, in the ceramic cup at $20 \mathrm{~cm}$ depth and that at $150 \mathrm{~cm}$ depth in NIQ III, the Ni content was always particularly high compared to the others, indicating significant lateral variability. Hexavalent chromium concentrations in the soil solutions were relatively high, reaching $3.9 \mu \mathrm{mol} \mathrm{L}^{-1}$ in December 2006 (Tab. 1). In NIQ II, Cr(VI) concentrations tended to increase between 20 to $70 \mathrm{~cm}$ and decrease slightly below, with a higher concentration observed at $70 \mathrm{~cm}$, whereas the $\mathrm{Cr}(\mathrm{VI})$ concentrations in NIQ III remained homogeneous with depth (approximately $1.0 \mu \mathrm{mol} \mathrm{L}^{-1}$ ) (Tab. 1). Over time, Cr(VI) concentrations tended to decrease from December 2006 to January 2007 , followed by a long-term increase from January to June 2007 (as shown for NIQII at 20 and $70 \mathrm{~cm}$ depth in Figure 3).

\section{Surface waters}

The $\mathrm{pH}$ of the rainwater was acidic $(\mathrm{pH}=4.8 \pm 0.05)$, and the ion concentrations were below the detection limits of the ICP-AES and the ionic chromatograph.

The $\mathrm{pH}$ of the water at the spring was neutral $(7.25 \pm 0.12)$, and the $\mathrm{pH}$ was higher at the outlet $(8.00 \pm 0.05)$. In surface waters, $\mathrm{Si}$ and $\mathrm{Mg}$ concentrations were dramatically higher than in the soil solutions and increased between the spring and the outlet, from 254 to 383 and 275 to $308 \mu \mathrm{mol} \mathrm{L}^{-1}$, respectively (Tab. 1). Finally, the $\mathrm{Ca}$ and $\mathrm{Na}$ concentrations were equivalent to those measured in the soil solutions.

The stream solution was free of $\mathrm{Fe}$ and $\mathrm{Al}$, but traces of $\mathrm{Mn}$ were present $\left(0.3 \pm 0.5 \mu \mathrm{mol} \mathrm{L}^{-1}\right)$ (Tab. 1$)$. The Ni concentrations at the spring and outlet were in the same range as the soil concentrations $\left(0.7-1 \mu \mathrm{mol} \mathrm{L}^{-1}\right)$, whereas the concentrations of $\mathrm{Cr}$, which occurred as $\mathrm{Cr}(\mathrm{VI})$, were lower, with values of 0.5 and $0.4 \mu \mathrm{mol} \mathrm{L}^{-1}$ for the spring and outlet, respectively.

Elemental concentrations in the runoff waters filtrated at $0.22 \mu \mathrm{m}$ were lower than those observed in the stream solutions. Si was the dominant element, with a concentration of $12.3 \pm 3.1 \mu \mathrm{mol} \mathrm{L}^{-1}$. Importantly, the $\mathrm{Cr}(\mathrm{VI}), \mathrm{Ni}$, and $\mathrm{Mn}$ concentrations were significant, with values of $0.8 \pm 0.4,0.2 \pm 0.1$, and 1.6 $\pm 0.2 \mu \mathrm{mol} \mathrm{L}^{-1}$, respectively (Tab. 1).

\section{Filtration fractionation}

More than 20 samples collected in February 2008 were analyzed following the filtration fractionation protocol, and the results are presented in Table 3. The concentrations of $\mathrm{Cr}, \mathrm{Ni}$, $\mathrm{Ca}, \mathrm{Mg}$, and $\mathrm{Si}$ in the different subsamples (unfiltered, $\theta_{0} ; 0.22$ $\left.>\theta_{1}>0.025 \mu \mathrm{m} ; 0.025>\theta_{2}>10 \mathrm{kDa} ; 10 \mathrm{kDa}>\theta_{3}\right)$ of both the soil and stream solutions were in the same range within the limits of analytical error (Tab. 3). The concentrations of $\mathrm{Fe}$ and $\mathrm{Al}$ in all soil solution fractions were always below the detection limits in all subsamples. However, in the runoff water, the Fe concentration was particularly high $\left(3,253 \mu \mathrm{mol} \mathrm{L}^{-1}\right)$ in the unfiltered water, whereas it was below the detection limit after filtration (Tab. 3). To a lesser extent, the concentrations of $\mathrm{Mn}, \mathrm{Cr}$, and $\mathrm{Ni}$ in the unfiltered runoff water also sharply decreased after filtration at $0.22 \mu \mathrm{m}$ : only $30 \%$ of the $\mathrm{Mn}, 7 \%$ of the $\mathrm{Cr}$, and $1 \%$ of the Ni remained after the $0.22 \mu \mathrm{m}$ filtration. The concentrations in all filtered fractions remained equivalent, at approximately $1.8,1.0$, and $0.2 \mu \mathrm{mol} \mathrm{L}{ }^{-1}$, for $\mathrm{Mn}, \mathrm{Cr}$, and $\mathrm{Ni}$, respectively. Therefore, metals are present in the runoff samples associated with Fe-colloids $>0.22 \mu \mathrm{m}$ and as free ions. Finally, the Si concentration in the unfiltered 
Table 3. Result of $\mathrm{Si}, \mathrm{Ca}, \mathrm{Mg}, \mathrm{Fe}, \mathrm{Al}, \mathrm{Mn}, \mathrm{Cr}$, and $\mathrm{Ni}$ of all filtration fractionation solution performed using a cascade filtration approach on a selection of soils and surface's solutions, and ratio between concentrations in the different size fractions expressed in \%. (n.f no filtered), < d.l. as below detection limit.

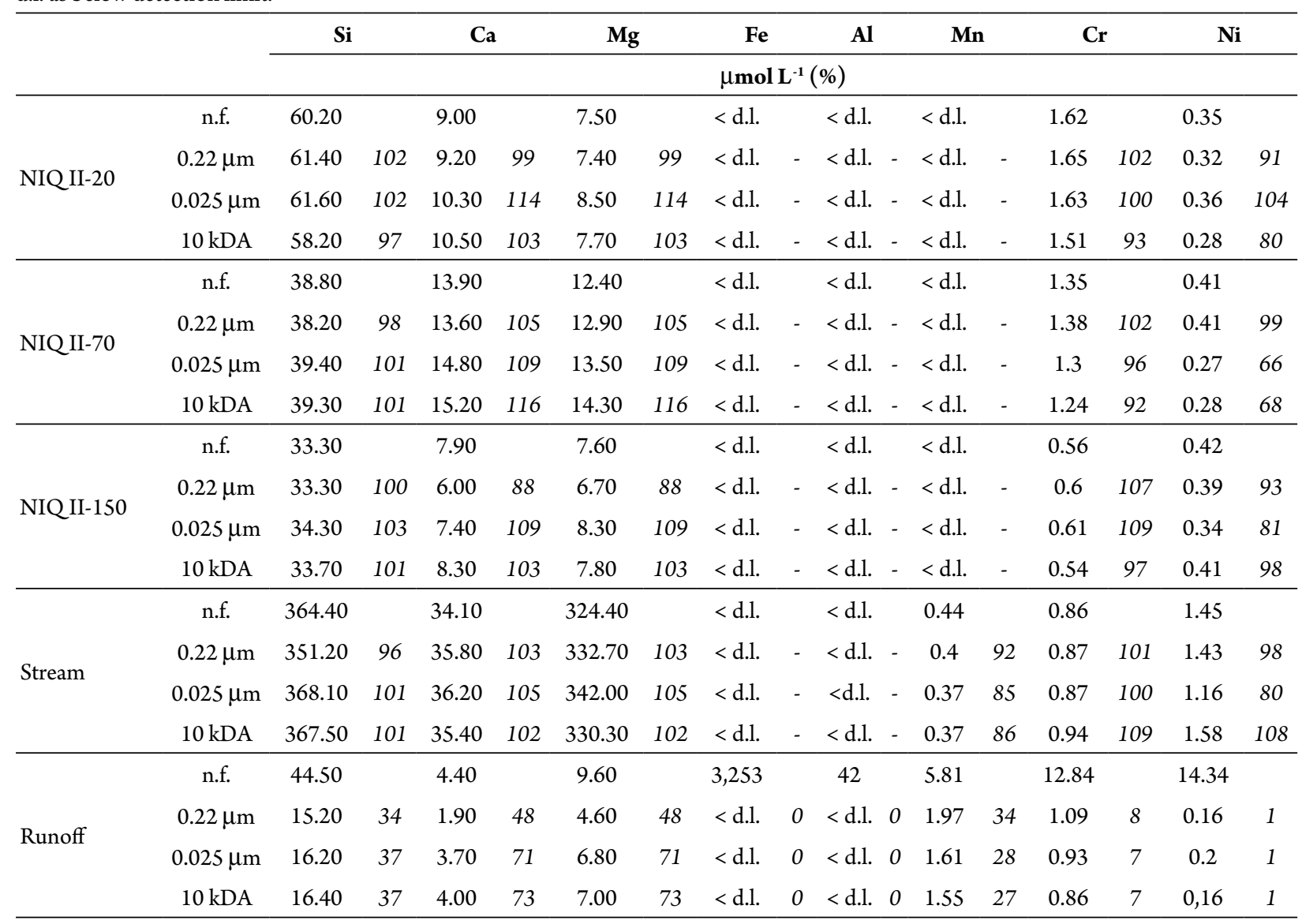

runoff solution was higher $\left(44.5 \mu \mathrm{mol} \mathrm{L}{ }^{-1}\right)$ than in the filtered solutions, in which it remained at approximately $16 \mu \mathrm{mol} \mathrm{L}^{-1}$.

\section{DISCUSSION}

\section{Serpentine syndrome and metal concentrations in soil solutions}

Niquelândia Ferralsols developed on ultramafic rocks are highly weathered and leached and, thus, poor in the most mobile elements, such as $\mathrm{Ca}, \mathrm{Mg}$, and $\mathrm{Si}$, and enriched in less mobile elements, such as $\mathrm{Fe}, \mathrm{Al}, \mathrm{Mn}, \mathrm{Cr}$, and $\mathrm{Ni}$ (Garnier et al. 2006, 2009a, 2009b, 2013). Accordingly, the soil solution chemistry was slightly acidic and poorly mineralized in the (B) horizon, although the solution was slightly more mineralized inside the topsoil due to the biodegradation of soil organic matter and the surface recycling. The particularly low concentration of nutrients, such as $\mathrm{K}$, has been recognized as one explanation for the low fertility of this type of soil. Solutions were not balanced with the main primary minerals of the dunite bedrock, such as olivine, but the dominant cations, i.e., Si and $\mathrm{Mg}$, were in agreement with the "ultramafic" nature of the soils. Soil solutions were free of $\mathrm{Fe}, \mathrm{Al}$, and $\mathrm{Mn}$, which is in agreement with the immobilization of such elements as oxides in unsaturated soil profiles. In contrast, the presence of metals, such as $\mathrm{Ni}$ and $\mathrm{Cr}$, which are slightly more soluble, was significant.
The chemical composition exhibited high variability, in agreement with the fact that several parameters control the content and speciation of soil solutions over time (e.g., local mineralogy, vegetation and biological activities, as well as water content and saturation).

Silica dominated the solution composition. In such slightly acidic solutions, aqueous $\mathrm{Si}$ species occurred predominantly in the form of neutral species, primarily $\mathrm{H}_{4} \mathrm{SiO}_{4}{ }^{\circ}$ (Gérard et al. 2008). The concentrations remained relatively constant throughout the soil profiles during both the rainy and dry seasons. Silica appears to be only slightly affected by edaphic conditions or biological processes (Fig. 3). Moreover, the concentrations observed are consistent with the solubility of quartz ( $\mathrm{Log}\left[\mathrm{H}_{4} \mathrm{SiO}_{4}{ }^{\circ}\right]$ of -4.4 to -4) (Maitat et al. 2000, Wonisch et al. 2008). The results also indicate that the $\mathrm{Si}$ buffering capacity of these soils is large, in agreement with the soil mineralogy and the presence of quartz as the only silicate minerals in both the bulk and fine fractions (Garnier et al. 2009b).

$\mathrm{Ca}$ and $\mathrm{Na}$ concentrations were in the same range as those reported by Lilienfein et al. (2000) in soil solutions from Brazilian savanna oxisols, highlighting the high degree of weathering of these Ferralsols. However, Mg concentrations were slightly higher in the Niquelândia soil solutions, which is explained by the UM nature of the parent material. $\mathrm{Mg}$ and $\mathrm{Ca}$ concentrations were in the same range as those reported by other studies on ultramafic soils (Proctor 1970, 
Anderson et al. 1973, Johnston and Proctor 1981, Gasser et al. 1994) but lower than those reported by Becquer et al. (2010). The chemical discrepancies between the topsoil and deeper horizons suggest that for different soil processes; the higher nutrient content in the topsoil solutions is associated with nutrient recycling. Nutrient cycling appears to be located at the surface and is likely related to plant development (Lucas et al. 1993). The rapid mineralization of organic matter likely promotes this feature and is emphasized by the large decrease in $\mathrm{NO}_{3}{ }_{3}$ with depth. Moreover, given the presence of $\mathrm{Mg}$-rich plants (Reeves et al. 2007) and consequently Mg-enriched litter in the topsoil, $\mathrm{Mg}$ concentrations are 3-fold higher in the topsoil than in deeper horizons.

$\mathrm{Ca}: \mathrm{Mg}$ molar ratios measured in the soil solutions were extremely low ( 0.65 to 1.32 ), as were the total and extractable Ca:Mg molar ratios measured in the soil matrix (data not shown). This imbalance has already been considered to be a specific feature of ultramafic soils (Whittaker 1954). Here, the ratio was lower than the values reported by Johnston and Proctor (1981), who studied less-developed "ultramafic" soils. In quite similar soils in New-Caledonia, Becquer et al. (2010) showed that the $\mathrm{Mg}$ : Ca molar ratio was close to unity. In a vegetation survey of the Brazilian ultramafic massifs, Reeves et al. (2007) showed that leaves from plants growing in the soils of these massifs have a low $\mathrm{Ca}: \mathrm{Mg}$ ratio, which ranges from 0.26 to 2.26. Moreover, this study noted the presence of plants that are particularly rich in $\mathrm{Ca}$ or $\mathrm{Mg}$ in those soils and contain 12,910 and $28,270 \mathrm{mg} \mathrm{kg}^{-1}$ of Ca and $\mathrm{Mg}$, respectively (Reeves et al. 2007). Given the composition of the soil solutions and the ratio in plant tissues, it appears that the plants of the Niquelândia massif can concentrate Ca relative to $\mathrm{Mg}$ or vice versa. The data obtained in this study (Tab. 2) demonstrates that the Ca:Mg ratio varies spatially and temporally; thus, variations in $\mathrm{Ca}$ and $\mathrm{Mg}$ in soil solutions can explain the large variations in the concentrations of these elements observed in plants.

Hexavalent chromium always represents more than $95 \%$ of the total Cr quantified by ICP-AES in surface waters. Even if the sampling method is not suitable for $\mathrm{Cr}$ (III) sampling (Becquer et al. 2010), given the slightly acidic $\mathrm{pH}$ and the large amount of iron oxides present in the soils (Garnier et al. 2009b), the Cr(III) is expected to be entirely sorbed (Fischer et al.2007) and consequently not mobile (Kotas and Stasicka 2000). The $\mathrm{Cr}$ (VI) concentrations remained high throughout the complete hydrological cycle (Fig. 3), and the field results confirm the high $\mathrm{Cr}(\mathrm{VI})$ lability measured in the laboratory by $\mathrm{KH}_{2} \mathrm{PO}_{4}$-extraction, Isotope Exchange Kinetic (IEK) and XANES (Garnier et al. 2006, 2009a, 2013). Cr(VI) was present in "truly" dissolved forms, as shown by the filtration fractionation (Tab. 3). Cr speciation is in agreement with other results obtained from tropical UM soils by Becquer et al. (2003, 2010) (Suppl. Fig.). Gasser et al. (1994) found that the Cr in soil solution was primarily (65-75\%) present in colloidal form. These results, being obtained from a poorly weathered serpentine soil developed under a cold mountain climate where the dominant pedogenetic process was cryofractionation, leading to the production of rock fragments and low chemical weathering, cannot be compared to presents results obtained in highly leached soils. The vertical distribution of $\mathrm{Cr}(\mathrm{VI})$ concentrations over the hydrological cycle agreed with the distribution of $\mathrm{Cr}(\mathrm{VI})$ availability in both the NIQ II and NIQ III profiles, as assessed via IEK (Garnier et al. 2009a). Moreover, Garnier et al. (2009a) also identified a high correlation between the granulometric clay content and $\mathrm{Cr}(\mathrm{VI})$ availability. An increase in the sorption of oxyanions onto Fe-oxides, consistent with the $\mathrm{pH}$ increase with depth, may also significantly influence $\mathrm{Cr}(\mathrm{VI})$ mobility. Finally, the presence of organic matter can explain the lower concentrations of $\mathrm{Cr}(\mathrm{VI})$ in topsoil solutions compared to mineral horizons, as it can reduce $\mathrm{Cr}$ (VI) into $\mathrm{Cr}$ (III) in topsoil, which is subsequently immobilized in its trivalent form. However, given the contrasting effects of the various components or properties of the soils, no simple relationship exists between $\mathrm{Cr}$ concentrations in soil solutions and other soil properties, e.g., $\mathrm{pH}$, and organic matter and iron oxide contents.

$\mathrm{Cr}(\mathrm{VI})$ concentrations in soil solutions were higher than toxicity standards, such as recommended levels for irrigation water $\left(<0.15 \mu \mathrm{mol} \mathrm{L}^{-1}\right)$ or freshwater life $\left(<0.02 \mu \mathrm{mol} \mathrm{L}^{-1}\right)$ (Pawlisz et al. 1997, WHO 1998). Therefore, Cr(VI) probably contributes to the endemism seen within the study region, i.e., one of the features of the serpentine syndrome (Reeves et al. 2007). However, unlike $\mathrm{Ni}$, the content of $\mathrm{Cr}$ in all analyzed plant leaves was low (Reeves, personal communication). Thus, Cr seems not to be absorbed by plants and stored in roots, as observed by Shanker et al. (2005). However, due to the high toxicity of $\mathrm{Cr}(\mathrm{VI})$ even at low concentrations, $\mathrm{Cr}$ must have an indirect effect on the biota, and the ecosystem has likely acquired a tolerance capacity.

$\mathrm{Ni}$ concentrations in solutions were of the same order of magnitude as those observed in a New Caledonian UM outcrop (Becquer et al. 2010). However, the local variability in $\mathrm{Ni}$ concentrations was large. In NIQII, the Ni concentrations were larger in the topsoil than in the deeper horizons, whereas the concentrations were homogeneous in NIQIII, except for local anomalies. Ni concentrations can be analyzed using the profile structures of both soils, which were presented in a previous study (Garnier et al. 2009b). NIQ II presents a superficial horizon with a larger content of organic matter and deeper horizons rich in iron oxides. In the surface horizons, it is thought that the high $\mathrm{Ni}$ content in the soil solutions is controlled by organic matter or litterfall mineralization in the topsoil. Litter-fall from Ni-hyperaccumulating plants (Reeves et al. 2007) contributes to the addition of Ni to the surface horizon. This feature is in agreement with the solid speciation of $\mathrm{Ni}$ in these soils, with high contents of $\mathrm{Ni}$ associated with organic matter (between 100 and $400 \mathrm{mg} \mathrm{kg}^{-1}$, Garnier 2008). In deeper horizons, the slight increase in the content of iron oxides, associated with the decrease in the organic matter content and the increase of $\mathrm{pH}$, promotes Ni sorption on goethite (Fischer et al. 2007) (Suppl. Fig.). Otherwise, the local variability in Ni concentrations in the NIQ III solutions collected at the same depth (from the detection limit to $2.8 \mu \mathrm{mol} \mathrm{L}^{-1}$ ) could be related to local-scale mineralogical variability. The presence of relicts composed of weathered $\mathrm{Ni}$-smectite in the upper part of 
the NIQ III profile may locally increase Ni availability and mobility. This finding is in good agreement with the results of Becquer et al. (2010), who showed a lower availability of $\mathrm{Ni}$ in a highly weathered, iron-rich soil in a mountain piedmont (OUE1) relative to a colluvio-alluvial soil containing some poorly weathered silicates (OUE3). Nickel concentrations in the soil solutions also often exceed the toxic threshold for freshwater given in the WHO (1998) guidelines for drinking water quality or for biota reported by L'Huillier and Edighoffer (1996) and Becquer et al. (2010). However, $\mathrm{Ca}^{2+}$ and $\mathrm{Mg}^{2+}$ are known to alleviate the phytotoxicity of $\mathrm{Ni}$ (Proctor and McGowan 1976, Gabrielli and Pandolfini 1984, Robertson 1985), and their presence may limit Ni toxicity.

The serpentine syndrome has been proposed and is related to a low level of nutrients ( $\mathrm{N}, \mathrm{P}$, and $\mathrm{K})$, a Ca:Mg imbalance, as well as the presence of metals that can decrease fertility (Whittaker 1954, Brooks 1987, Bini et al. 2017). Nutrient contents were not lower than those observed in other oxisols of the Cerrado region (Lilienfein et al. 2000), i.e., high leached soils. However, Ca:Mg ratios were low in the topsoil, and both $\mathrm{Ni}$ and $\mathrm{Cr}(\mathrm{VI})$ are highly labile. At a minimum, the present results are in agreement with two of the three serpentine syndrome conditions, i.e., the low $\mathrm{Ca}: \mathrm{Mg}$ ratio and the presence of labile metals, leading to limited fertility of the ultramafic outcrop area of Niquelândia. This limitation likely contributes to the high degree of endemism observed in the ultramafic massif. Rapid recycling of nutrients and $\mathrm{Ni}$, i.e., via uptake of the elements released by the mineralization of litter, appears to occur, thereby limiting the leaching of essential elements. This feature confers greater fertility through the enhanced availability of nutrients, which mitigates one of the typical traits of areas with ultramafic substrates. This feature also produces higher Ni concentrations in the topsoil solutions. The present results suggest that, in deep, leached soils developed in ultramafic rock, the (hyper)accumulation of Ni by plants and the recycling of Ni-rich organic matter can indirectly contribute to maintaining high $\mathrm{Ni}$ concentrations in the topsoil and thus contribute to the high degree of endemism on the outcrop. Similar features seem to occur at $\mathrm{Mg}$ concentrations that can maintain higher $\mathrm{Mg}$ bioavailability relative to $\mathrm{Ca}$ in topsoil. Both features are in agreement with the ecological traits of these environments, as reflected by the serpentine syndrome.

\section{Metal mobility}

The $\mathrm{pH}$ value of the spring water (7.25) was higher than the values observed in the soil solutions (6.05), likely due to hydrolysis processes in the deeper part of the profiles, i.e., the saprolite, where Ni-bearing clays and weatherable primary minerals are abundant. In surface water, cation concentrations decrease in the order $\mathrm{Mg}^{2+}>\mathrm{Ca}^{2+}>\mathrm{Na}^{+}>\mathrm{K}^{+}$, and the $\mathrm{Ca} / \mathrm{Mg}$ ratio for all water samples was lower than 1 , due to the low $\mathrm{Ca}$ concentration in ultramafic bedrocks, similar to the findings of Kaprara et al. (2015) for UM water in Greece and Mcclain and Maher (2016) in the United States. The elevated Mg and Si concentrations in the stream solutions in relation to the soil solutions underline this feature. The large content of $\mathrm{Mg}$ and Ca may be balanced by alkalinity (not measured), which agrees with the alkaline $\mathrm{pH}$. These findings are in good agreement with those of McClain and Maher (2016) and with the solubility of the main silicate minerals in the soil and the saprolite, i.e., $\mathrm{UM}$ rock-solution equilibrium. The $\mathrm{Mg}$, $\mathrm{Ca}$, and $\mathrm{Si}$ concentrations were lower than those reported by McClain and Maher (2016), whereas those of $\mathrm{Cr}$ (considering both $\mathrm{Cr}(\mathrm{VI})$ and $\mathrm{Cr}(\mathrm{VI})+\mathrm{Cr}(\mathrm{III})$ reported) and $\mathrm{Ni}$ are higher. On the one hand, the Si concentrations in the soil, which are nearly 40 to $100 \mu \mathrm{M} \mathrm{l}^{-1}$, are closely related to the solubility product of quartz, which is close to a $\mathrm{Log}\left[\mathrm{H}_{4} \mathrm{SiO}_{4}{ }^{\circ}\right]$ value of -4.4 to -4 (Maitat et al. 2000, Wonisch et al. 2008). In turn, the Si concentrations in the spring and the outlet, which are nearly 300 $\mu \mathrm{Ml}^{-1}$, are much higher due to the lower resistance to weathering of the olivine or serpentine encountered in the deeper parts of the profiles.

Particular attention was given to the composition of the solutions collected during February 2008 to verify the presence of colloids and their role as metal-bearing phases, as observed by Gasser et al. (1994) for soils developed on ultramafic rock in the Davos region. For a given element, lower concentrations in one of two different size fractions indicate the presence of a particulate form of this element. This finding, as well as variations in the ratios between certain elements among different size fractions, can be used to determine the impact, if any, of different components on metals and colloid formation (Garnier et al.2011). The presence of $\mathrm{Cr}(\mathrm{VI})$ and $\mathrm{Ni}$ in the filtered solutions, even at $10 \mathrm{kDa}$, in both soil and surface waters from the stream and runoff, proves that these elements are mobile at the catchment scale in "truly" dissolved forms. More than $66 \%$ of the $\mathrm{Ni}$ and $92 \%$ of the $\mathrm{Cr}(\mathrm{VI})$ in the soil solutions, as well as all of the $\mathrm{Ni}$ and $\mathrm{Cr}(\mathrm{VI})$ in the stream, were present in dissolved form, the remainder being in colloidal forms. The Ni concentration in the spring was close to the soil concentrations, and the concentration decreased slightly, whereas the Cr concentration in the spring was lower than the soil concentrations and remained constant along the watercourse. The behavior of $\mathrm{Ni}$ and $\mathrm{Cr}(\mathrm{VI})$ is very different than that of Si and $\mathrm{Mg}$. Unlike those of the latter species, the concentrations of $\mathrm{Ni}$ and $\mathrm{Cr}$ (VI) in the soil solutions did not increase after passing through the saprolite. This difference in $\mathrm{Ni}$ and $\mathrm{Cr}$ dynamics from the soil to the spring with regards to $\mathrm{Si}$ and $\mathrm{Mg}$ can be explained by different mechanisms, including:

- dilution by soil solutions that are relatively poor in $\mathrm{Cr}$ or $\mathrm{Ni}$ (in less developed soils);

- weathering and precipitation of different kinds of metal-bearing phases;

- sorption/desorption mechanisms operating between $\mathrm{Ni}$, which occurs as cations, and $\mathrm{Cr}(\mathrm{VI})$, which occurs as oxyanions, and the surface charges of minerals;

- the reduction of $\mathrm{Cr}$ to a less mobile form, i.e., $\mathrm{Cr}$ (III).

The adsorption of Ni on goethite, which forms quickly during weathering of UM primary minerals, appears to be a key factor. Indeed, the increase beyond $\mathrm{pH} 7$ in the saprolite leads to the total sorption of Ni in goethite (Fischer et al.2007). Therefore, soil solutions coming from the highly weathered upper part of the soil profile are the main source of mobile 
nickel in the environment. For $\mathrm{Cr}(\mathrm{VI})$, the increase in $\mathrm{pH}$ in the saprolite should decrease the retention of $\mathrm{Cr}(\mathrm{VI})$ anions by goethite (Garnier et al.2009a). According to Dai et al. (2009), free $\mathrm{Cr}(\mathrm{III})$ ions and $[\mathrm{CrOH}]^{2+}$ are the forms of $\mathrm{Cr}(\mathrm{III})$ that oxidize to $\mathrm{Cr}(\mathrm{VI})$ most readily. However, these $\mathrm{Cr}$ species disappear beyond $\mathrm{pH}$ 7. Therefore, the production of $\mathrm{Cr}(\mathrm{VI})$ would be limited in the saprolite, unlike the weathered soil. Soil solutions coming from the highly weathered upper part of the soil profile are also the main source of mobile $\mathrm{Cr}(\mathrm{VI})$ in the environment.

Runoff waters filtered at $0.22 \mu \mathrm{m}$ were entirely free of $\mathrm{Fe}$ and $\mathrm{Al}$, whereas the unfiltered samples featured high concentrations of $\mathrm{Fe}$, showing that $\mathrm{Fe}$ was mobile as a particulate material. This observation is in agreement with in situ observations during rainstorms, in which oxide particles were mobilized at the catchment scale in this area, where UM rocks outcrop. In the sample tubes, these particles $(>0.22 \mu \mathrm{m})$ remained dispersed in the runoff waters for several months. Thus, despite being larger in size than the typical cut-off for colloids, this fraction behaved as a colloidal fraction. A XANES measurement on this fraction has revealed that a portion of the $\mathrm{Cr}$ was present in its hexavalent form in this fraction (Garnier et al. 2013). This fraction, the $>0.22 \mu \mathrm{m}$ fraction, involved metal transfer on the outcrop in "colluvial" transport from the hill to the footslope, as already discussed by Garnier et al. (2009b), as well as to the surrounding ecosystems. This fraction is also rich in $\mathrm{Al}, \mathrm{Mn}, \mathrm{Ni}$, and $\mathrm{Cr}$, and this colloidal transport and mobility may promote metal dispersion, thereby acting as a vector of metal mobility.

\section{CONCLUSION}

This investigation of soil solutions and surface waters from the Niquelândia ultramafic massif improves our understanding of the unique qualities of this ultramafic area and the serpentine syndrome. The low Ca: $\mathrm{Mg}$ ratio in the soil solutions was consistent with both the ultramafic features and the Mg-rich vegetation. Moreover, $\mathrm{Cr}$, mainly in its hexavalent form, and Ni occurred in the topsoil solutions as "truly" dissolved ions. $\mathrm{Cr}(\mathrm{VI})$ concentrations remained high, and no change in the oxidation state was observed in the soil solutions through a complete hydrological cycle. These metals' lability, coupled with the large Ca:Mg imbalance, contribute to the biodiversity selectivity within the outcrop area of these UM rocks, highlighting once again the close relationship between the serpentine syndrome and the availability of metals in soils.

Niquelândia UM soils might constitute a source of labile metals, mainly $\mathrm{Ni}$ and $\mathrm{Cr}(\mathrm{VI})$, which are partly exported to surrounding areas of the ultramafic massif. Two main environmental dispersal forms of metals have been: "truly" dissolved metals and colloidal transfer of $\mathrm{Ni}$ and $\mathrm{Cr}$ associated with Fe-oxides. The highly weathered upper parts of the soil are more likely to be the source of mobile, "truly" dissolved $\mathrm{Ni}$ and $\mathrm{Cr}$, whereas saprolite can act as a sink of metals. Colloidal transfer of Fe-oxides and associated metals occurs during intense rain events. However, this metal's mobility may have an impact on the surrounding ecosystems, particularly for plants and microorganisms not adapted to these metals.

\section{ACKNOWLEDGMENTS}

This work was supported by the Collège Doctoral FrancoBrésilien and by the $\mathrm{CNPq}$ (Conselho Nacional de Desenvolvimento Cientifico e Tecnológico, Brazil) under contract No. 475124/2006-5 and No. 445423/2014-5; 420697/2018-7 and 302722/2018-1. The authors wish to thank the Votorantim Metais and more particularly the staff of the mine of Niquelândia. The authors are thankful to A. Becquer, Dr M.I. Lopes de Oliveira, Dr D. Néia Eberhardt, and Dr N.P. Benito for their assistance during soil solutions sampling, and the IRD and Embrapa of Brasilia for technical supports. The authors also wish to thank for the DOC measurement and tribute the paper to C. Garnier from the University of Toulon.

\section{ARTICLE INFORMATION}

Manuscript ID: 20200092. Received on: 04/18/2020. Approved on: 10/14/2020.

All authors participated in all phases of the study, sampling, analyses, discussion, and writing of the paper.

Competing interests: The authors declare no competing interests.

\section{REFERENCES}

Alexander M. 2000. Aging, bioavailability, and overestimation of risk from environmental pollutants. Environmental Science \& Technology, 34(20):4259-4265. https://doi.org/10.1021/es001069+

Anacker B.L. 2014. The nature of serpentine endemism. American Journal of Botany, 101(2):219-224. https://doi.org/10.3732/ajb.1300349

Anderson A.J., Meyer D.R., Mayer F.K. 1973. Heavy metal toxicities: levels of nickel, cobalt, and chromium in the soil and plants associated with visual symptoms and variation in growth of an oat crop. Australian Journal of Agricultural Research, 24(4):557-571. https://doi.org/10.1071/ AR9730557

Bartlett J.R., James B.R. 1996. Chromium. In: Sparks D.L. (Ed.). Methods of Soil Analysis: part 3, Chemical Methods. Madison: Soil Science Society of America, American Society of America, p. 683-701.
Becquer T., Quantin C., Boudot J.P. 2010. Toxic levels of metals in Ferralsols under natural vegetation and crops in New Caledonia. European Journal of Soil Science, 61(6):994-1004. https://doi.org/10.1111/j.1365-2389.2010.01294.x

Becquer T., Quantin C., Rotte-Capet S., Ghanbaja J., Mustin C., Herbillon A. 2006. Sources of trace metals in Ferralsols in New Caledonia. European Journal of Soil Science, 57(2):200-213. https://doi. org/10.1111/j.1365-2389.2005.00730.x

Becquer T., Quantin C., Sicot M., Boudot J.P. 2003. Chromium availability in ultramafic soils from New-Caledonia. Science of the Total Environment, 301(1-3):251-261. https://doi.org/10.1016/S0048-9697(02)00298-X

Bini C., Maleci L., Wahsha M. 2017. Potentially toxic elements in serpentine soils and plants from Tuscany (Central Italy). A proxy for soil remediation. Catena, 148(Part 1):60-66. https://doi.org/10.1016/j.catena.2016.03.014 
Bolaños-Benítez V., van Hullebusch E., Garnier J., Quantin C., Tharaud M., Lens P., Sivry Y. 2018. Assessing chromium mobility in natural surface waters: Colloidal contribution to the isotopically exchangeable pool of chromium ( $\mathrm{E}_{\mathrm{Cr}}^{\mathrm{w}}$ value). Applied Geochemistry, 92:19-29. https://doi. org/10.1016/j.apgeochem.2018.02.007

Brooks R.R. 1987. Serpentine and its vegetation: a multidisciplinary approach. Portland: Diocorides Press.

Brown Jr. G.E., Calas G. 2011. Environmental mineralogy - Understanding element behavior in ecosystems. Comptes Rendus Geoscience, 343(2-3):90-112. https://doi.org/10.1016/j.crte.2010.12.005

Cordeiro P., Oliveira C.G. 2017. The Goiás Massif: Implications for a preColumbia 2.2-2.0 Ga continent- wide amalgamation cycle in central Brazil. Precambrian Research, 298:403-420. https://doi.org/10.1016/j. precamres.2017.06.021

Dai R., Liu J., Yu C., Sun R., Lan Y., Mao J.D. 2009. A comparative study of oxidation of $\mathrm{Cr}(\mathrm{III})$ in aqueous ions, complex ions and insoluble compounds by manganese-bearing mineral (birnessite). Chemosphere, 76(4):536-541. https://doi.org/10.1016/j.chemosphere.2009.03.009

Dublet G., Juillot F., Morin G., Fritsch E., Fandeur D., Ona-Nguema G., Brown Jr. G.E. 2012. Ni speciation in a New Caledonian lateritic regolith: A quantitative X-ray absorption spectroscopy investigation. Geochimica et Cosmochimica Acta, 95:119-133. https://doi.org/10.1016/j. gca.2012.07.030

Fandeur D., Juillot F., Morin G., Olivi L., Cognigni A., Webb S.M., Ambrosi J.P., Fritsch E., Guyot F., Brown Jr. G.E. 2009. XANES evidence for oxidation of $\mathrm{Cr}(\mathrm{III})$ to $\mathrm{Cr}(\mathrm{VI})$ by $\mathrm{Mn}$-oxides in a lateritic regolith developed on serpentinized ultramafic rocks of New Caledonia. Environmental Science \& Technology, 43(19):7384-7390. https://doi.org/10.1021/es900498r

Fischer L., Brümmer G.W., Barrow N.J. 2007. Observations and modeling of the reactions of 10 metals with goethite: adsorption and diffusion processes. European Journal of Soil Science, 58(6):1304-1315. https://doi. org/10.1111/j.1365-2389.2007.00924.x

Gabrielli R., Pandolfini T. 1984. Effect of $\mathrm{Mg} 2+$ and $\mathrm{Ca} 2+$ on the response to nickel toxicity in a serpentine endemic and nickelaccumulating species. Physiologia Plantarum, 62(4):540-544. https://doi. org/10.1111/j.1399-3054.1984.tb02796.x

Garnier J. 2008. Sources et dynamique du chrome dans les sols ultramafiques de Niquelândia, Brésil. PhD Thesis, Paris XI University, Paris.

Garnier J., Quantin C., Echevarria G., Becquer T. 2009a. Assessment of chromate availability in tropical ultramafic soils using isotopic exchange kinetics. Journal of Soils and Sediments, 9(5):468-475. https://doi. org/10.1007/s11368-009-0062-4

Garnier J., Quantin C., Guimarães E., Garg V.K., Martins E.S., Becquer T. $2009 \mathrm{~b}$. Understanding the genesis of ultramafic soils and catena dynamics in Niquelândia, Brazil. Geoderma, 151(3-4):204-214. https://doi. org/10.1016/j.geoderma.2009.04.020

Garnier J., Quantin C., Guimarães E.M., Vantelon D., Montargès-Pelletier E., Becquer T. 2013. Cr(VI) genesis and dynamics in Ferralsols developed from ultramafic rocks: The case of Niquelândia, Brazil. Geoderma, 193-194:256-264. https://doi.org/10.1016/j.geoderma.2012.08.031

Garnier J., Quantin C., Martins E.S., Becquer T. 2006. Solid speciation and availability of chromium in ultramafic soils from Niquelandia, Brazil. Journal of Geochemical Exploration, 88(1-3):206-209. https://doi.org/10.1016/j. gexplo.2005.08.040

Garnier J.M., Hurel C., Garnier J., Lenoble V., Garnier C., Ahmed K.M., Rose J. 2011. Strong chemical evidence for high Fe(II)-colloids and low As-bearing colloids $(200 \mathrm{~nm}-10 \mathrm{kDa})$ contents in groundwater and flooded paddy fields in Bangladesh: A size fractionation approach. Applied Geochemistry, 26(9-10):1665-1672. https://doi.org/10.1016/j. apgeochem.2011.04.023

Gasser U.G., Juchler S.J., Sticher H. 1994. Chemistry and speciation of soil water from serpentinitic soils - importance of colloids in the transport of $\mathrm{Cr}$, $\mathrm{Fe}, \mathrm{Mg}$, and Ni. Soil Science, 158(5):314-322.

Gérard F., Mayer K.U., Hodson M.J., Ranger J. 2008. Modelling the biogeochemical cycle of silicon in soils: Application to a temperate forest ecosystem. Geochimica et Cosmochimica Acta, 72(3):741-758. https://doi. org/10.1016/j.gca.2007.11.010
Hseu Z.-Y., Su Y.-C., Zehetner F., Hsi H.-C. 2017. Leaching potential of geogenic nickel in serpentine soils from Taiwan and Austria. Journal of Environmental Management, 186(Pt 2):151-157.https://doi.org/10.1016/j. jenvman.2016.02.034

Jaffré T., Brooks R.R., Lee J., Reeves R.D. 1976. Sebertia acuminata: a hyperaccumulator of nickel from New Caledonia. Science, 193(4253):579-580. https://doi.org/10.1126/science.193.4253.579

Johnston W.R., Proctor J. 1981. Growth of serpentine and non-serpentine races of Festuca rubra in solutions simulating the chemical conditions in a toxic serpentine soil. Journal of Ecology, 69(3):855-869. https://doi. org/10.2307/2259641

Kalis E.J.J., Temminghoff E.J.M., Town R.M., Unsworth E.R., van Riemsdijk W.H. 2008. Relationship between metal speciation in soil solution and metal adsorption at the root surface of ryegrass. Journal of Environmental Quality, 37(6):2221-2231. https://doi.org/10.2134/jeq2007.0543

Kanellopoulos C., Argyraki A., Mitropoulos P. 2015. Geochemistry of serpentine agricultural soil and associated groundwater chemistry and vegetation in the area of Atalanti, Greece. Journal of Geochemical Exploration, 158:22-33. https://doi.org/10.1016/j.gexplo.2015.06.013

Kaprara E., Kazakis N., Simeonidis K., Coles S., Zouboulis A.I., Samaras P., Mitrakas M. 2015. Occurrence of Cr (VI) in drinking water of Greece and relation to the geological background. Journal of Hazardous Materials, 281:2-11. https://doi.org/10.1016/j.jhazmat.2014.06.084

Kazakou E., Dimitrakopoulos P.G., Baker A.J.M., Reeves R.D., Troumbis A.Y. 2008. Hypotheses, mechanisms and trade-offs of tolerance and adaptation to serpentine soils: from species to ecosystem level. Biological Reviews, 83(4):495-508. https://doi.org/10.1111/j.1469-185x.2008.00051.x

Kotas J., Stasicka Z. 2000. Chromium occurrence in the environment and methods of its speciation. Environmental Pollution, 107(3):263-283. https://doi.org/10.1016/S0269-7491(99)00168-2

Kruckeberg A.R. 1984. California serpentines: flora, vegetation, geology, soils, and management problems. Berkeley: University of California Press.

L'Huillier L.,Edighoffer S. 1996. Extractability of nickel andits concentrations in cultivated plants in Ni rich ultramafic soils of New Caledonia. Plant and Soil, 186:255-264. https://doi.org/10.1007/BF02415521

Lilienfein J., Wilcke W., do Carmo Lima S., Vilela L., Thomas R., Zech W. 2000. Nutrient concentrations in soil solution of some Brazilian oxisols under conventional and no-tillage systems in the early part of the rainy season. Australian Journal of Soil Research, 38(4):851-866. https://doi. org/10.1071/SR99113

Lucas Y., Luizao F.J., Chauvel A., Rouiller J., Nahon D. 1993. The relation between biological-activity of the rain-forest and mineral-composition of soils. Science, 260(5107):521-523. https://doi.org/10.1126/ science. 260.5107 .521

Maitat O., Boudot J.P., Merlet D., Rouiller J. 2000. Aluminum chemistry in two contrasted acid forest soils and headwater streams impacted by acid deposition, Vosges mountains, N.E. France. Water, Air, and Soil Pollution, 117:217-243. https://doi.org/10.1023/A:1005132321147

McClain C.N., Maher K. 2016. Chromium fluxes and speciation in ultramafic catchments and global rivers. Chemical Geology, 426:135-157. https://doi.org/10.1016/j.chemgeo.2016.01.021

Myers N., Mittermeier R.A., Mittermeier C.G., Da Fonseca G.A.B., Kent J. 2000. Biodiversity hotspots for conservation priorities. Nature, 403:853858. https://doi.org/10.1038/35002501

Oze C., Fendorf S., Bird D.K., Coleman R.G. 2004. Chromium geochemistry in serpentinized ultramafic rocks and serpentine soils from the Franciscan complex of California. American Journal of Science, 304(1):67-101. https:// doi.org/10.2475/ajs.304.1.67

Patel-Sorrentino N., Lucas Y., Eyrolle F., Melfi A.J. 2007. Fe, Al and S species and organic matter leached off a ferrallitic and podzolic soil system from Central Amazonia. Geoderma, 137(3-4):444-454. https://doi. org/10.1016/j.geoderma.2006.10.002

Pawlisz A.V., Kent R.A., Schneider U.A., Jefferson C. 1997. Canadian water quality guidelines for chromium. Environmental Toxicology and Water Quality, 12(2):123-183. https://doi.org/10.1002/ (SICI)1098-2256(1997)12:2\%3C123::AID-TOX4\%3E3.0.CO;2-A 
Pędziwiatr A., Kierczak J., Waroszewski J., Waroszewski J., Ratié G., Quantin C., Ponzevera E. 2018. Rock-type control of Ni, Cr, and Co phytoavailability in ultramafic soils. Plant and Soil, 423:339-362. https://doi.org/10.1007/ s11104-017-3523-3

Proctor J. 1970. Magnesium as a toxic element. Nature, 227(5259):742-743. https://doi.org/10.1038/227742a0

Proctor J., McGowan I.D. 1976. Influence of magnesium on nickel toxicity. Nature, 260:134. https://doi.org/10.1038/260134a0

Proctor J., Nagy L. 1992. Ultramafic rocks and their vegetation: An overview. In: Baker A.J.M., Proctor J., Reeves R.D. (Eds.). The vegetation of ultramafic (serpentine) soils. Andover: Intercept, p. 469-494.

Quantin C., Becquer T., Berthelin J. 2002. Mn-oxide: a major source of easily mobilisable $\mathrm{Co}$ and $\mathrm{Ni}$ under reducing conditions in New Caledonia Ferralsols. Comptes Rendus Geoscience, 334(4):273-278. https://doi. org/10.1016/S1631-0713(02)01753-4

Ratié G., Garnier J., Calmels D., Vantelon D., Guimarães E., Monvoisin G., Nouet J., Ponzevera E., Quantin C. 2018. Nickel distribution and isotopic fractionation in a Brazilian lateritic regolith: Coupling $\mathrm{Ni}$ isotopes and $\mathrm{Ni}$ K-edge XANES. Geochimica et Cosmochimica Acta, 230:137-154. https:// doi.org/10.1016/j.gca.2018.03.026

Ratié G., Jouvin D., Garnier J., Rouxel O., Miska S., Guimarães E., Cruz Vieira L., Sivry Y., Zelano I., Montarges-Pelletier E., Thil F., Quantin C. 2015. Nickel isotope fractionation during tropical weathering of ultramafic rocks. Chemical Geology, 402:68-76. https://doi.org/10.1016/j. chemgeo.2015.02.039

Ratié G., Quantin C., Maia de Freitas A., Echevarria G., Ponzevera E., Garnier J. 2019. The behavior of nickel isotopes at the biogeochemical interface between ultramafic soils and $\mathrm{Ni}$ accumulator species. Journal of Geochemical Exploration, 196:182-191. https://doi.org/10.1016/j.gexplo.2018.10.008

Reatto A., Bruand A., Silva E.M., Martins E.S., Brossard M. 2007. Hydraulic properties of the diagnostic horizon of latosols of a regional toposequence across the Brazilian Central Plateau. Geoderma, 139(1-2):51-59. https:// doi.org/10.1016/j.geoderma.2007.01.003

Reeves R.D., Baker A.J.M., Becquer T., Echevarria G., Miranda Z.J.G. 2007. The Flora and Biogeochemistry of the Ultramafic Soils of Goiás State, Brazil. Plant and Soil, 293(1):107-119. https://doi.org/10.1007/ s11104-007-9192-x
Robertson A.I. 1985. The poisoning of roots of Zea mays by nickel ions, and the protection afforded by magnesium and calcium. New Phytologist, 100(2):173-189. https://doi.org/10.1111/j.1469-8137.1985.tb02769.x

Robles-Camacho J., Armienta M.A. 2000. Natural chromium contamination of groundwater at Leon Valley, Mexico. Journal of Geochemical Exploration, 68(3):167-181. https://doi.org/10.1016/S0375-6742(99)00083-7

Samantary S. 2002. Biochemical responses of Cr-tolerant and Cr-sensitive mung bean cultivars grown on varying levels of chromium. Chemosphere, 47(10):1065-1072. https://doi.org/10.1016/S0045-6535(02)00091-7

Shanker A.K., Cervantes C., Loza-Tavera H., Avudainayagam S. 2005. Chromium toxicity in plants. Environment International, 31(5):739-753. https://doi.org/10.1016/j.envint.2005.02.003

Sharma D.C., Chatterjee C., Sharma C.P. 1995. Chromium accumulation and its effect on wheat (Triticum aestivum L. cv. Dh 2204) metabolism. Plant Science, 111 (2):145-151. https://doi.org/10.1016/0168-9452(95)04230-R

Weng C.H., Huang C.P., Allen H.E., Cheng A.H.D., Sanders P.F. 1994. Chromium leaching behavior in soil derived from chromite ore processing waste. Science of the Total Environment, 154(1):71-86. https://doi. org/10.1016/0048-9697(94)90615-7

Whittaker R.H. 1954. The ecology of serpentine soils: a symposium. Ecology, 35(2):258-288. https://doi.org/10.2307/1931126

Wonisch H., Gérard F., Dietzel M., Jaffrain J., Nestroy O., Boudot J.P. 2008. Occurrence of polymerized silicic acid and aluminum species in two forest soil solution with different acidity. Geoderma, 144(3-4):435-445. https:// doi.org/10.1016/j.geoderma.2007.11.022

World Health Organization (WHO) 1998. Guidelines for drinking-water quality. 2. ed. Addendum to Volume 1. Recommendations. Geneva: World Health Organization.

Zayed A.M., Terry N. 2003. Chromium in the environment: factors affecting biological remediation. Plant and Soil, 249:139-156. https://doi. org/10.1023/A:1022504826342

Zelano I., Sivry Y., Quantin C., Gélabert A., Tharaud M., Jouvin D., Montarges-Pelletier E., Garnier J., Pichon R., Nowak S., Miska S., Abollino O., Benedetti M.F. 2013. Colloids and suspended particulate matters influence on Ni availability in surface waters of impacted ultramafic systems in Brazil. Colloids and Surfaces A: Physicochemical and Engineering Aspects, 435:36-47. https://dx.doi.org/10.1016/j.colsurfa.2013.02.051 